\title{
PROGRAM PEMBIASAAN KARAKTER SISWA MELALUI PENDAMPINGAN SEKOLAH PEDALAMAN DI KALIMANTAN TENGAH
}

\author{
Asriana Kibtiyah ${ }^{1}$, Ikhsan Gunadi ${ }^{2}$ \\ ${ }^{1}$ Program Studi Pendidikan Guru Madrasah Ibtidaiyah, Universitas Hasyim Asy'ari Jombang \\ ${ }^{2}$ Program Doktor Manajemenen Pendidikan, Universitas Negeri Malang \\ ${ }^{1}$ alc.indonesia@gmail.com \\ 2ikhsangunadi@gmail.com
}

\begin{abstract}
Schools as the leading education operators have a heavy responsibility as with schools in the interior of Central Kalimantan province. Through social responsibility programs, mining companies located in rural villages carry out school assistance programs. By involving experts and practitioners in the world of education, the character habituation mentoring program is carried out in a measured and planned manner. This study is to describe the original conditions of the schools in the interior. This research is qualitative in nature and has a journalistic descriptive case study background which is expected to reveal the problems of rural schools. In this study, a process of testing the ability of teachers and students was also carried out, observing teacher competence in teaching, and so on. Research data were obtained in addition to field observations as well as interviews with teachers, students and parents as well as community leaders including officials in government and companies. The results showed that the teacher's ability to teach and literate was relatively low. The findings of this study are regarding the existence of school principals who do not function in managing schools so that most rural schools run without a clear direction and purpose. Another finding regarding the culture of local people who do not have the awareness of realizing child-friendly education and educating children to become quality human beings is also not an easy thing
\end{abstract}

Keywords: Character Habituation, Outback School

\begin{abstract}
Abstrak: Sekolah sebagai operator pendidikan terdepan memiliki tanggung jawab yang tidak ringan sebagaimana dengan sekolah-sekolah yang ada di pedalaman provinsi Kalimantan Tengah. Melalui program tanggung jawab sosial, perusahaan tambang yang berada di desa pedalaman melakukan program pendampingan sekolah. Dengan melibatkan para pakar dan praktisi dunia pendidikan, program pendampingan pembiasaan karakter dijalankan secara terukur dan terencana. Penelitian ini untuk mendeskripsikan kondisi asli sekolah-sekolah di pedalaman. Penelitian ini bersifat kualitatif dan berlatarbelakang studi kasus deskriptif jurnalistik yang diharapkan dapat mengungkapkan permasalahan sekolah pedalaman. Dalam penelitian ini juga dilakukan proses pengujian atas kemampuan guru maupun siswa, mengobservasi kompetensi guru dalam mengajar, dan sebagainya. Data penelitian diperoleh selain melalui pengamatan lapangan juga wawancara kepada guru, siswa dan orangtua serta para tokoh masyarakat termasuk pejabat di Pemerintahan maupun perusahaan. Hasil penelitian menunjukkan bahwa kemampuan guru masih terbilang rendah dalam mengajar dan berliterasi. Temuan penelitian ini terhadap keberadaan kepala sekolah yang tidak berfungsi mengelola sekolah sehingga sebagian besar sekolah pedalaman berjalan tanpa arah dan tujuan yang jelas. Temuan lain berkenaan budaya masyarakat setempat yang belum memiliki kesadaran mewujudkan pendidikan yang ramah anak, dan mendidik anak menjadi manusia berkualitas juga bukan hal yang mudah.
\end{abstract}

Kata Kunci: Pembiasaan Karakter, Sekolah Pedalaman

\section{Pendahuluan}

Pendidikan adalah bentuk ikhtiyar dari suatu masyarakat dan bangsa guna menjaga keberlangsungannya dengan membekali generasi muda agar menjadi masyarakat dan bangsa yang lebih baik di masa depan. Melalui pewarisan budaya dan karakter yang telah dimiliki suatu masyarakat merupakan cara menjaga keberlangsungan tersebut. Dalam proses pendidikan budaya dan karakter bangsa, secara aktif peserta didik dapat mengembangkan potensi dirinya, melakukan proses internalisasi, dan penghayatan nilai-nilai menjadi kepribadian yang teraktualisasi, mengembangkan kehidupan masyarakat 
yang lebih sejahtera, serta mengembangkan kehidupan bangsa yang bermartabat. Persoalan budaya dan karakter bangsa ini tengah menjadi sorotan tajam media cetak dan elektronik. Permasalahan yang muncul seperti korupsi, kasus kekerasan, kejahatan seksual, perusakan sumberdaya alam, tawuran massal, gaya hidup konsumtif dan hedonis, kehidupan politik yang tidak sehat dan tidak produktif, dan sebagainya menjadi topik pembahasan hangat di berbagai media. Dengan berkaca pada kondisi itu maka menjadi penting kehadiran pendidikan sebagai upaya dan langkah preventif karena pendidikan akan membantuk dan membangun generasi baru bangsa yang lebih baik (Gafuri, 2015). Menurut Sonhadji (2014), pendidikan berfungsi sebagai transmission of knowledge, skills, values, and culture. Mengalirkan pengetahuan, keterampilan, nilai, dan budaya Sehingga dalam pendidikan aspek-aspek rasionalitas, martabat, etika, dan estetika sangat ditekankan.

Apabila ditinjau lebih jauh dengan melihat fakta-fakta di dunia pendidikan dan masyarakat saat ini, maka kita bisa lihat sejumlah peristiwa yang memilukan dan tragis. Misalnya, kasus guru memukul siswa yang banyak terjadi di sekolah, ataupun siswa memukul guru hingga tewas sebagaimana kasus yang terjadi di Sampang Madura. Kasus kekerasan sesama siswa berupa perundungan (bullying) kerap memakan korban fisik dan psikis bahkan nyawa. Sasongko (2017) melaporkan bahwa, "Seorang guru di SMP Muhammadiyah 8 Kota Batu, Jawa Timur dilaporkan atas dugaan pemukulan oleh siswinya. ASR dilaporkan CDK, siswa kelas 8 sekolah tersebut atas tuduhan penganiayaan".

Menurut Komisi Perlindungan Anak Indonesia (KPAI) selama 2007, dari 555 kasus kekerasan terhadap anak, 11,8\% di antaranya terjadi di sekolah, dan sepanjang 2007-2009, kasus tertinggi adalah kasus kekerasan psikis dengan total 2.094 kasus, diikuti oleh kekerasan seksual berjumlah
1.858 kasus dan kekerasan fisik sebanyak 1.382 kasus (Ulina, 2013). Dalam laporan yang berbeda dimana tingkat kekerasan di sekolah kian mengkhawatirkan. Menurut KPAI, 7 dari 10 siswa (sekitar 84\%) pernah mengalami kekerasan di sekolah, dengan $45 \%$ pelakunya adalah sivitas sekolah. Para pelaku kekerasan di sekolah sebanyak $40 \%$ adalah siswa berusia 13-15 tahun yang juga pernah mengalami kekerasan fisik oleh teman, $75 \%$ siswa mengakui sebagai pelaku. Sedangkan siswa perempuan sebanyak 22\% menyebutkan bahwa pelaku kekerasan adalah sivitas sekolah, dan $50 \%$ anak dilaporkan pernah di-bully saat bersekolah (Seftiawan, 2017).

Data di atas yang diperkuat dengan hasil riset International Center for Research on Women (ICRW) dan Plan International menunjukkan terdapat $84 \%$ anak di Indonesia mengalami kekerasan di sekolah. Angka tersebut lebih tinggi dari angka 70\% yang merupakan rata-rata di Asia. Harian Republika merilis bahwa angka kasus kekerasan di sekolah di Indonesia (84\%) ini lebih tinggi dari Pakistan (43\%), Nepal (79\%), Kamboja (73\%), dan Vietnam (79\%) (Mukhtar \& Zuraya, 2017). Sementara itu, data UNICEF menyebutkan, 1 dari 3 anak perempuan dan 1 dari 4 anak laki-laki di Indonesia pernah mengalami kekerasan. Data tersebut menggambarkan bahwa kasus kekerasan di Indonesia lebih sering dialami oleh anak-anak perempuan dibandingkan anak laki-laki. (Qodar, 2015). Kondisi di atas membentuk persepsi negatif terhadap sekolah dan dunia pendidikan. Hal itulah yang mendasari tuntutan Kongres Anak Indonesia tahun 2016 di Mataram kepada Pemerintah dimana salah satu butir berbunyi: "Jadikan sekolah dan kurikulum kami ramah anak sampai ke daerah pelosok".

Sedangkan terkait dengan tuntutan pendidikan secara global, UNESCO mencanangkan empat pilar pendidikan kesejagatan, yang terdiri dari: learning to know, learning to do, learning to live together, dan learning to be (Delors et al., 1999). Dalam konteks learning to know, 
semestinya pendidikan mampu mendorong siswa agar mampu menguasai instrumen pengetahuan sebagai alat maupun tujuan hidup. Learning to do terkait dengan upaya mendorong siswa agar mampu bertindak kreatif di lingkungannya. Learning to live together terkait dengan upaya agar siswa mampu berperan dan bekerjasama dengan orang lain. Sedangkan learning to be terkait dengan upaya memaksimalkan perkembangan siswa seutuhnya.

Freire (1985) membedakan pendidikan dalam dua hal, yakni sistem yang dominatif dan sistem yang humanis. Sistem pendidikan yang dominatif condong meniadakan prinsip kesadaran aktif. Menurut Yamin (2012), pendidikan dengan sistem ini menjadikan guru sebagai pelaku tunggal yang mengetahui dan menunjukkan ilmu pengetahuan kepada siswa sebagai orang yang (dianggap) tidak tahu apa-apa. Sedangkan sistem pendidikan yang humanis sebaliknya, sistem pembelajarannya pun berbeda dengan sistem dominatif. Sistem ini memberikan kebebasan siswa untuk mengenali dan menangkap kehidupan nyata secara kritis. Melalui pendekatan humanis akan siswa akan tumbuh dan memiliki kemerdekaan belajar dalam satu lingkungan sekolah yang memanusiakan manusia. Itulah sekolahnya manusia (Chatib, 2015).

Dalam kaitannya dengan hal di atas, maka menjadi hal utama dalam sekolah adalah merupakan upaya terbentuknya karakter (Character Building), dan bukan semata-mata hanya memberikan pengetahuan dan keterampilan. Melalui Perpres No.87 Tahun 2017, Pemerintah mendorong dunia pendidikan baik jalur formal, non formal dan informal untuk menyelenggarakan pendidikan karakter. Perpres menyebutkan bahwa Penguatan Pendidikan Karakter (PPK) merupakan gerakan pendidikan di bawah tanggung jawab satuan pendidikan guna memperkuat karakter peserta didik melalui harmonisasi olah hati, olah rasa, olah pikir, dan olah raga dengan pelibatan dan kerjasama antara satuan pendidikan, keluarga, dan masyarakat sebagai bagian dari Gerakan Nasional Revolusi Mental (GNRM) (Setkab RI, 2017).

Jadi program PPK mengamanahkan kepada sekolah di pelosok Indonesia untuk melaksanakan dengan sebaiknya, tidak terkecuali sekolah yang ada di Desa Barunang Kecamatan Kapuas Tengah Kabupaten Kapuas Provinsi Kalimantan Tengah yang berada di pedalaman dan letaknya berada di dekat eksploitasi dan eksplorasi tambang batubara.

Desa Barunang yang merupakan daerah yang masuk ke dalam ring satu wilayah tambang PT Asmin Bara Bronang (ABB) menjadi sasaran utama untuk diberdayakan terutama dalam sektor pendidikan dan kesejahteraan masyarakat. Di sektor pendidikan, PT ABB melakukan program pendampingan dalam pendidikan karakter di sekolah-sekolah dengan melibatkan akademisi dan profesional pendidikan.

\section{Metode}

Penelitian ini dilakukan dengan pendekatan kualitatif yang sudah dikenal oleh peneliti bidang ilmu sosial dan pendidikan. Sejumlah alasan juga dikemukakan yang intinya bahwa penelitian kualitatif memperkaya hasil penelitian kuantitatif. Sugiyono (2017), berpendapat bahwa penelitian kualitatif dilaksanakan untuk membangun pengetahuan melalui suatu pemahaman dan penemuan. Pendekatan penelitian kualitatif adalah suatu proses penelitian dan pemahaman yang didasarkan pada metode untuk menyelidiki suatu fenomena sosial dan masalah manusia. Pada penelitian ini peneliti membuat suatu gambaran kompleks, meneliti fakta-fakta temuan lapangan, laporan rinci dari pandangan subjek penelitian dan melakukan studi pada situasi yang alami (Iskandar, 2009).

Penelitian kualitatif dilakukan pada kondisi yang senatural-naturalnya dan bersifat penemuan. Dalam penelitian kualitatif, khadiran peneliti adalah eleman kunci dari penelitian. Oleh karena itu 
peneliti harus memiliki bekal teori dan wawasan yang luas agar dapat bertanya, menganalisis dan mengkonstruksi objek yang diteliti menjadi lebih jelas. Penelitian ini lebih menekankan pada makna dan terikat nilai. Lebih lanjut, Iskandar (2009) menegaskan bahwa hakikat penelitian kualitatif adalah mengamati orang dalam lingkungan hidupnya berinteraksi dengan mereka, berusaha memahami bahasa dan tafsiran mereka tentang dunia sekitarnya, mendekati atau berinteraksi dengan orangorang yang berhubungan dengan fokus penelitian dengan tujuan mencoba memahami, menggali pandangan dan pengalaman mereka untuk mendapat informasi atau data yang diperlukan.

Selain itu, penelitian ini juga bersifat deskriptif yang umumnya bertujuan untuk menggambarkan secara sistematis fakta dan karakteristik objek ataupun subjek secara tepat (Sugiyono, 2015). Hal ini selaras dengan tujuan dilakukannya penelitian ini, yaitu untuk mendapatkan permasalahan yang berkaitan dengan bidang pendidikan maupun perilaku manusia (Darmadi, 2011). Untuk itu, maka dalam strategi yang dilakukan selama penelitian ini juga sangat fleksibel yang interaktif seperti melakukan observasi secara langsung ke sekolah, observasi partisipatif, wawancara, mempelajari dokumen, teknik dokumentasi dan sebagainya yang mana semuanya agar mendapatkan data yang valid (Sukmadinata, 2015). Hal ini juga selaras sebagaimana yang disampaikan oleh Darmadi (2011) bahwa pengumpulan dan analisis data penelitian kualitatif bersifat interaktif, berlangsung dalam lingkaran yang saling tumpang tindih sehingga langkah-langkahnya fleksibel, tergantung pada strategi dan data yang telah diperoleh sebelumnya.

Penelitian ini juga mengukur kondisi guru dan siswa seperti kemampuan literasi, pemahaman membaca dan lain-lain. Analisis data juga dilakukan sesuai kaidah dalam penelitian kuantitatif dan eksperimen, di samping analisis terhadap temuan data kualitatif (Moleong, 2000;
Nawawi, 2003; Sukardi, 2008; Ulfatin, 2015). Dengan menggunakan analisis sederhana terhadap pengukuran atas kondisi sekolah, guru dan siswa maka diperoleh informasi terhadap kondisi nyata yang mengkonfirmasi atas fakta-fakta di lapangan.

\section{Hasil dan Pembahasan}

\section{Data Hasil Penelitian}

Desa Barunang adalah salah satu desa yang berada di wilayah Kecamatan Kapuas Tengah, Kabupaten Kapuas, Provinsi Kalimantan Tengah, Indonesia.yang mayoritas penduduknya beragama Hindu Kaharingan dan Kristen Protestan. Bahasa yang digunakan masyarakat Barunang dulunya adalah Bahasa dayak kuwatan, sekarang bahasa yang paling populer digunakan adalah Bahasa Kadorih (Uut Danum), Barinjei (Uut Siang), dan Kahayan. Desa yang memiliki luas $337 \mathrm{~km}^{2}$ dengan jumlah penduduk 1170 jiwa ini didominasi oleh kawasan hutan dan eksplorasi pertambangan batubara (Wikipedia, 2011). Desa ini merupakan satu dari 13 desa yang ada di Kecamatan Kapuas Tengah yang terbilang berada di pedalaman.

Oleh karena berada di pedalaman yang akses informasi dan jalannya juga masih sangat terbatas, karena infrastruktur juga belum memadai, maka sudah tentu keberadaan sekolah-sekolah di desa tersebut juga kurang memadai. Namun, dengan adanya program CSR (Corporate Social Responsibilty) perusahaan yang bertanggung jawab terhadap lingkungan termasuk kesejahteraan warga desa dalam mengenyam pendidikan yang berkualitas, sebagian sekolah cukup terbantu dan diberdayakan melalui program-program yang dilaksanakan oleh perusahaan yang melakukan eksplorasi dan ekspolitasi tambang batubara di desa tersebut.

Program pendampingan dilakukan pada enam sekolah yang ada di Desa Barunang yang tersebar di empat dusun terdiri dari satu unit PAUD/TK, dua unit 
SD negeri, dua unit SD swasta dan satu unit SMP negeri. Fokus program pada pembiasaan karakter dan peningkatan kompetensi guru.

\section{a. Fakta dan Kondisi Sekolah}

Secara geografis, lokasi penelitian dimana sekolah-sekolah berada terbilang tidak mudah dijangkau oleh transportasi dan komunikasi. Di daerah yang sebagian besar merupakan hutan belum ada listrik dan telpon kabel maupun sinyal telpn seluler. Belum lagi infrastruktur jalan yang masih dari tanah yang dipadatkan dengan lapisan pasir dan batu yang sepenuhnya dilakukan oleh perusahaan tambang.

Kondisi bangunan SD negeri yang dibangun Pemerintah pada tahun 1998 hingga saat ini belum ada perbaikan dan renovasi bangunan, termasuk penggantian meja-kursi belajar siswa yang sudah rusak. Bangunan yang seluruhnya terbuat dari bahan kayu tampak rusak di bagian lantai dan plafon. Sedangkan TK swasta, SD swasta dan SMP negeri seluruh sarana dan prasarananya diadakan oleh perusahaan PT ABB dalam beberapa tahun terakhir ini.

Sedangkan kondisi guru dan siswa secara umum dapat dilihat pada tabel berikut.

Tabel 1. Data umum sekolah

\begin{tabular}{|c|c|c|c|c|}
\hline Sekolah & $\begin{array}{r}\text { Kepala } \\
\text { Sekolah }\end{array}$ & Status & $\begin{array}{c}\text { Status } \\
\text { Bangunan }\end{array}$ & $\begin{array}{c}\text { Thn } \\
\text { Berdiri }\end{array}$ \\
\hline $\begin{array}{l}\text { TK Tunas } \\
\text { Bangsa } \\
\text { Sakakarangan }\end{array}$ & $\begin{array}{l}\text { Belum } \\
\text { ada }\end{array}$ & Swasta & $\begin{array}{l}\text { Dibangun } \\
\text { PT ABB }\end{array}$ & 2018 \\
\hline $\begin{array}{l}\text { SD Tunas } \\
\text { Bangsa } \\
\text { Sakakarangan }\end{array}$ & $\begin{array}{l}\text { Belum } \\
\text { ada }\end{array}$ & Swasta & $\begin{array}{l}\text { Dibangun } \\
\text { PT ABB }\end{array}$ & 2018 \\
\hline $\begin{array}{l}\text { SDN } \\
\text { Tumbang } \\
\text { Mamput }\end{array}$ & Ada & Negeri & $\begin{array}{l}\text { Milik } \\
\text { Pemerintah }\end{array}$ & 1991 \\
\hline $\begin{array}{l}\text { SDN } \\
\text { Barunang }\end{array}$ & $\begin{array}{l}\text { Masih } \\
\text { PLT }\end{array}$ & Negeri & $\begin{array}{l}\text { Milik } \\
\text { Pemerintah }\end{array}$ & 1991 \\
\hline $\begin{array}{l}\text { SD } \\
\text { Pendarawah }\end{array}$ & Ada & Swasta & $\begin{array}{l}\text { Dibangun } \\
\text { PT ABB }\end{array}$ & 2016 \\
\hline $\begin{array}{l}\text { SMPN } \\
\text { Kapuas } \\
\text { Tengah }\end{array}$ & $\begin{array}{l}\text { Masih } \\
\text { PLT }\end{array}$ & Negeri & $\begin{array}{l}\text { Dibangun } \\
\text { PT ABB }\end{array}$ & 2018 \\
\hline
\end{tabular}

\section{b. Kuantitas dan Kualitas Guru}

Dalam kondisi geografis yang berada di wilayah pedalaman dimana akses jalan maupun komunikasi serba terbatas, tentu menjadi hambatan dan tantangan bagi ketersediaan guru. Tidak banyak orang yang bersedia ditempatkan di sekolahsekolah pedalaman dengan kondisi yang serba minus tersebut, sehingga yang terjadi adalah minimnya guru yang bisa memenuhi kualifikasi sebagaimana ketentuan dan persyaratan sebagai standar penyelenggaraan di satuan pendidikan.

Sementara itu apabila dilihat secara kuantitas dari masing-masing sekolah, maka dapat tergambar dalam tabel berikut.

Tabel 2. Jumlah Siswa dan Guru

\begin{tabular}{|c|c|c|c|c|}
\hline \multirow[t]{2}{*}{ No } & \multirow[t]{2}{*}{ Nama Sekolah } & \multicolumn{3}{|c|}{ Jumlah } \\
\hline & & Siswa & $\begin{array}{l}\text { Guru } \\
\text { ASN }\end{array}$ & $\begin{array}{l}\text { Guru } \\
\text { Honor }\end{array}$ \\
\hline 1 & TK Tunas Bangsa & 42 & 0 & 2 \\
\hline 2 & SD Tunas Bangsa & 40 & 0 & 6 \\
\hline 3 & $\begin{array}{l}\text { SDN Tumbang } \\
\text { Mamput }\end{array}$ & 62 & 1 & 9 \\
\hline 4 & SDN Barunang & 72 & 3 & 5 \\
\hline 5 & SD Pendarawah & 48 & 1 & 4 \\
\hline 6 & $\begin{array}{l}\text { SMP N Kapuas } \\
\text { Tengah }\end{array}$ & 56 & 1 & 5 \\
\hline \multicolumn{2}{|c|}{ Jumlah } & 320 & 6 & 31 \\
\hline
\end{tabular}

Dari tabel tersebut dapat dihitung jumlah rasio antara guru dan siswa di masing-masing sekolah yaitu (1) TK Tunas Bangsa memiliki rasio 1:22, (2) SD Tunas Bangsa memiliki rasio $1: 8$, (3) SDN Tumbang Mamput memiliki rasio 1:6, (4) SDN Barunang memiliki rasio 1:9, SD Pendarawah memiliki rasio $1: 10$; dan SMPN Kapuas Tengah memiliki rasio 1:11. Secara keseluruhan siswa dan guru di enam sekolah tersebut rata-rata memiliki rasio guru dan siswa sebesar 1:9 Angka rasio tersebut masih dalam jangkauan dari batas normal sesuai PP No.74 Tahun 2008 Pasal 17 yaitu sebesar 1:15 (jenjang TK) dan 1:20 (jenjang SD-SMP).

Data tersebut belum ditinjau dari kualifikasi masing-masing setiap guru di sekolah dimana masih banyak guru yang belum memenuhi kualifikasi standar sebagai seorang guru, termasuk dalam pemenuhan standar kompetensi profesional. Di banyak sekolah terdapat guru yang masih berpendidikan SMA dan tidak memiliki ijazah sebagai sarjana di bidang pendidikan dari perguruan tinggi. Inilah yang mengganjal guru dalam pemenuhan syarat administrasi sehingga akan menghambat proses sertifikasi guru yang 
6| Asriana Kibtiyah, dkk : Program pembiasaan karakter ...

bersangkutan. Lebih lanjut dapat dilihat pada tabel berikut untuk masing-masing sekolah.

Tabel 3. Kualifikasi Pendidikan Guru

\begin{tabular}{llll}
\hline \multirow{2}{*}{ Nama Sekolah } & \multicolumn{3}{c}{ Pendidikan Terakhir } \\
\cline { 2 - 4 } & S1 & S1 Non & Diploma/ \\
TK Tunas Bangsa & 0 & 0 & 2 \\
SD Tunas Bangsa & 3 & 1 & 2 \\
SDN Tumbang & 5 & 3 & 2 \\
Mamput & & & \\
SDN Barunang & 4 & 3 & 1 \\
SD Pendarawah & 1 & 1 & 3 \\
SMP N Kapuas Tengah & 4 & 1 & 1 \\
Jumlah & 17 & 9 & 11 \\
Rata-rata & 2,83 & 1,5 & 1,83 \\
\% & $46 \%$ & $24,3 \%$ & $29,7 \%$ \\
\hline Sumber: Sekolah masing-masing diolah ALC Indonesia
\end{tabular}

Berdasarkan latar belakang pendidikan, guru yang lulusan S1 Kependidikan sebesar $46 \%$ dan yang di luar itu ada $44 \%$. Terdapat $10 \%$ guru yang masih belum sarjana S1 maka bakal menjadi hambatan dan tantangan sendiri bagi sekolah dalam meningkatkan grid akreditasi. Sedangkan $10 \%$ guru yang bukan berlatarbelakang kependidikan akan menjadi kendala guru untuk sampai pada jenjang sertifikasi.

Pada penelitian awal melalui pengamatan lapangan dan wawancara diperoleh data dan fakta di setiap sekolah. Temuan fakta lapangan tersebut bersifat kualitatif yang dihasilkan dari proses pengamatan, observasi dan wawancara narasumber seperti guru dan kepala sekolah serta pihak dari PT ABB.

Pada sekolah TK-SD Tunas Bangsa yang pada awalnya merupakan sekolah satu atap terdapat temuan a) pembelajaran Kelas 1-3 dan 4-5 di dalam satu kelas; b) ruang kelas terbatas karena menggunakan rumah tinggal yang berisi 2 kamar saja; c) ruang bermain yang terbatas sehingga siswa bermain di dalam kelas yang sangat sempit; d) guru merasa belum mampu mengelola pendidikan PAUD dan TK serta menangani siswa bermasalah; e) Kepala sekolah belum definitif; e) belum tersedia wahana untuk permainan, dan belum ada halaman sekolah.

Adapun fakta yang ditemukan di SDN Tumbang Mamput seperti a) pelajaran olahraga disatukan untuk semua kelas (1-6) selama dua jam dalam sepekan; b) perpustakaan belum tertata, buku kurang memadai, rak bantuan PT ABB kurang terawat; c) info dari guru, bahwa Kepala Sekolah sering terlambat bahkan sering tidak hadir; d) kompetensi guru masih di bawah rata-rata, terlihat dari saat guru mengajar di kelas dengan cara konvensional dan tidak atraktif; e) perlengkapan (prasarana) untuk pendidikan jasmani/keolahragaan belum tersedia yang memadai; f) alat/perangkat pembelajaran IPA bantuan dari Pemerintah belum dimanfaatkan, masih tersimpan di boks; g) kepala sekolah membolehkan guru untuk mencubit bahkan memukul di bagian tertentu yang tidak berbahaya. Ini disampaikan oleh Kepala Sekolah saat wawancara; h) pendidikan karakter diwujudkan melalui "Buku Pintar" yang difasilitasi oleh PT ABB. Tapi ini dirasa masih belum efektif dan berjalan secara ajeg; i) peran dan fungsi kepala sekolah tidak dijalankan secara efektif, karena kompetensi yang dinilai kurang memadai dan motivasi mendidik yang lemah.

Hal yang hampir sama juga ditemukan di SDN Barunang, yang secara lebih lengkap seperti a) ruang kelas masih cenderung kosong, kurang rapi dan teratur; b) fisik gedung tampak kurang terawat; c) sudah dapat bantuan bangunan untuk "Rumah Pintar" dari PT ABB; d) kompetensi guru masih di bawah rata-rata, terlihat dari saat guru mengajar di kelas; e) ketidaktahuan guru menangani siswa bermasalah; f) ada guru kelas yang tidak hadir dan diisi dengan guru lain; g) perpustakaan masih menyatu dengan ruang guru; dan h) lokal kelas masih kurang. Ada ruang yang digunakan untuk dua kelas.

Sementara itu pada sekolah swasta SD Pendarawah ditemukan fakta-fakta seperti, a) gedung relatif sudah memadai; b) prasarana sekolah masih terbatas; c) metode pengajaran guru masih konvensional; d) rumah pintar yang berada di lingkungan sekolah sangat membantu proses pembelajaran setelah pulang sekolah; e) belum tersedia guru agama, 
sehingga tidak ada pengajaran agama untuk siswa.

Pada SMPN 4 Kapuas Tengah juga ditemukan fakta seperti a) guru relatif masih muda dan belum berpengalaman namun memiliki semangat yang tinggi; b) gedung tengah dalam pembangunan; c) Kepala Sekolah belum definitif; d) guru mengeluhkan ketiadaan sarana untuk meningkatkan kompetensi; e) kurangnya referensi dan sumber belajar bagi guru; f) Pejabat Kepala Sekolah merasa perlu belajar dan tahu tentang tata kelola sekolah yang benar sehingga dapat maju dan berkembang; g) administrasi tentang kurikulum dan silabus sekolah belum ada; h) guru mengeluh mengalami kesulitan dalam menangani siswa bermasalah.

Temuan fakta-fakta di lapangan tersebut menjadi dasar untuk dilakukannya proses selanjutnya, seperti melakukan program pendampingan pada setiap sekolah, dan memberikan perlakuan melalui program pembiasaan karakter kepada siswa.

\section{c. Program Pendampingan Sekolah}

Program pendampingan ini berawal dari kepedulian perusahaan PT ABB terhadap lingkungan dimana proses eksplorasi dan eksploitasi tambang batubara dilakukan. Desa Barunang adalah wilayah terdekat yang menjadi prioritas utama PT ABB sebagai sasaran utama program tanggungjawab sosial dan lingkungan (TJSL). Ketentuan ini terkandung dalam UU No. 4 Tahun 2009 tentang pertambangan mineral dan batubara pasal 1 angka 28 yang berbunyi: "usaha untuk meningkatkan kemampuan masyarakat, baik secara individual maupun kolektif, agar menjadi lebih baik tingkat kehidupannya”. Ketentuan tentang TJSL ini juga tercantum dalam peraturan lain seperti UU No.25/2007 tentang penanaman modal; jo. UU No.22/2001 tentang minyak dan gas bumi; jo UU No.40/2007 tentang perseroan terbatas; jo. UU No.21/2014 tentang panas bumi; jo. UU No.13/2011 tentang fakir miskin; jo. PP No.23/2010 tentang pelaksanaan kegiatan usaha pertambangan mineral dan batubara; jo. PP No.47/2012 tentang tanggungjawab sosial dan lingkungan perseroan terbatas (KlikLegal.com, 2018).

Berdasarkan ketentuan perundangan tersebut, maka PT ABB melakukan program pemberdayaan masyarakat melalui pendidikan terutama sekolah-sekolah yang ada di wilayah Desa Barunang. Ditambah dengan mempertimbangkan kondisi setiap sekolah yang masih jauh dari standar dalam penyelenggaraan pendidikan. Hal inilah yang menjadi salah satu alasan mengapa perlu adanya pendampingan di setiap sekolah di Desa Barunang.

Program pendampingan sekolah difokuskan pada peningkatan kompetensi guru dan pembiasaan karakter siswa.

\section{1) Peningkatan Kompetensi Guru}

Kompetensi guru yang terbilang di bawah standard diperlukan kegiatan pelatihan dan workshop guru profesional seperti: (a) pemahaman paradigma pendidikan; (b) pengetahuan kurikulum dan penyusunan silabus; (c) penyusunan rencana pembelajaran; (d) metode dan strategi pembelajaran kelas; dan (e) teknik evaluasi dan penilaian. Selain itu juga disisipkan pengetahuan tentang pendidikan karakter. Ini dilakukan agar guru juga memahami program pembiasaan karakter yang akan dilakukan kepada siswa.

Mengingat jarak antardusun dan sekolah yang saling berjauhan, maka kegiatan pelatihan dilaksanakan di dua titik kegiatan, pertama diadakan di kantor perusahaan $\mathrm{PT} \mathrm{ABB}$, dan kedua bertempat di SMP yang ada di Dusun Barunang. Pelatihan yang diadakan di kantor perusahaan untuk TK dan SD Tunas Bangsa serta SD Pendarawah. Sedangkan yang di Dusun Barunang, untuk SDN Tumbang Mamput, SDN Barunang dan SMPN 4 Kapuas Tengah. Kegiatan pelatihan dilaksanakan pada hari efektif sekolah selama 2-3 hari setiap periode, setelah jam belajar siswa pada pukul 13.00- 
8| Asriana Kibtiyah, dkk : Program pembiasaan karakter ...

16.00. Sehingga kegiatan tidak mengganggu jam efektif belajar siswa.

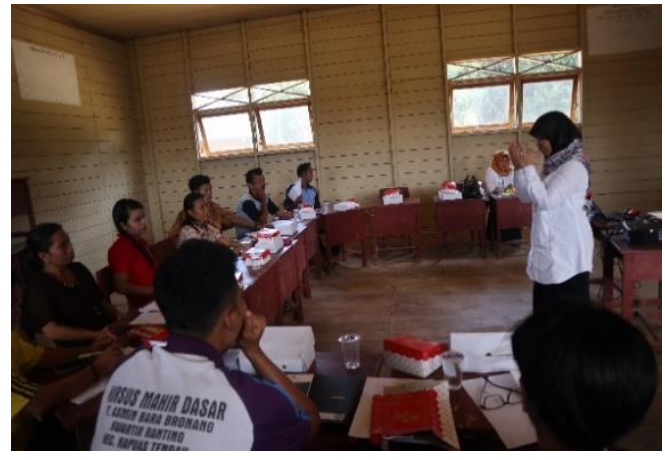

Gambar 1. Kegiatan Workshop Guru

Dari kegiatan pelatihan dan workshop yang diadakan sesuai, tingkat partisipasi kehadiran guru dapat dilihat pada tabel berikut.

Tabel 4. Prosentase Kehadiran Guru pada Workshop

\begin{tabular}{|c|c|c|c|c|c|}
\hline \multirow{2}{*}{ SEKOLAH } & \multicolumn{4}{|c|}{ PERIODE PELATIHAN } & \multirow{2}{*}{$\begin{array}{c}\text { RE } \\
\text { RATA }\end{array}$} \\
\hline & I & II & III & IV & \\
\hline $\begin{array}{l}\text { TK-SD TUNAS } \\
\text { BANGSA }\end{array}$ & $47 \%$ & $67 \%$ & $44 \%$ & $38 \%$ & $49 \%$ \\
\hline $\begin{array}{l}\text { SD PENDA } \\
\text { RAWAH }\end{array}$ & $28 \%$ & $50 \%$ & $33 \%$ & $22 \%$ & $33 \%$ \\
\hline $\begin{array}{l}\text { SDN TUMBANG } \\
\text { MAMPUT }\end{array}$ & $33 \%$ & $10 \%$ & $\mathbf{0 \%}$ & $47 \%$ & $23 \%$ \\
\hline $\begin{array}{l}\text { SDN } \\
\text { BARUNANG }\end{array}$ & $47 \%$ & $67 \%$ & $44 \%$ & $38 \%$ & $49 \%$ \\
\hline $\begin{array}{l}\text { SMP N } 4 \\
\text { KAPUAS } \\
\text { TENGAH }\end{array}$ & $50 \%$ & $39 \%$ & $33 \%$ & $50 \%$ & $43 \%$ \\
\hline $\begin{array}{c}\text { Rata-rata } \\
\text { keseluruhan }\end{array}$ & $41 \%$ & $47 \%$ & $31 \%$ & $39 \%$ & $39 \%$ \\
\hline
\end{tabular}

Tabel di atas dapat diperjelas dengan bentuk visual seperti gambar berikut.

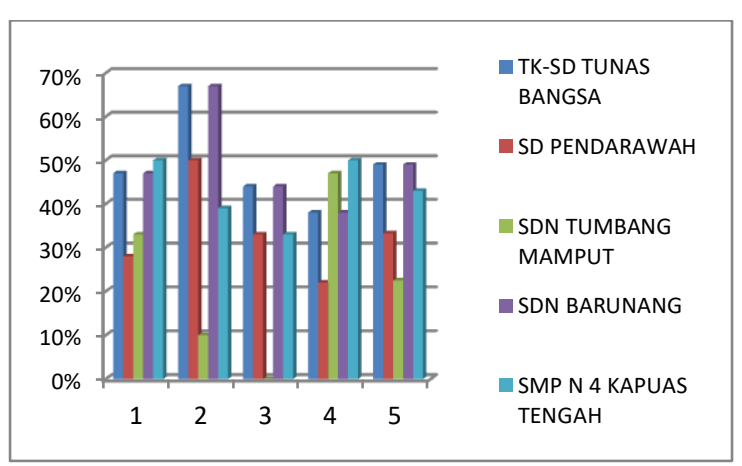

Gambar 2. Perbandingan Prosentase Kehadiran

Dari tabel dan grafik di atas dapat terlihat bahwa rata-rata per periode kehadiran guru pada pelatihan hanya mencapai 39\%. Demikian pula rata-rata kehadiran di tiap sekolah, tertinggi hanya $49 \%$. Bahkan ada sekolah yang memiliki rata-rata hanya $23 \%$ saja. Hal itu menunjukkan kecenderungan belajar guru terbilang rendah.

Rendahnya kehadiran dalam kegiatan pelatihan ini sangat menentukan pemahaman guru untuk dapat menguasai kompetensi tertentu yang dibutuhkan sebagai guru profesional. Kemampuan guru tidak akan meningkat jika pelatihan yang disediakan tidak diikuti dan dimanfaatkan untuk meningkatkan kualitas dirinya, terlepas dari kendala yang dialami oleh masing-masing individu guru.

Kendala alami yang dihadapi dalam pelaksanaan pelatihan ini adalah keterbatasan kendaraan yang membawa guru ke tempat pelatihan, sehingga harus bergantian menunggu dan menghabiskan waktu untuk pelatihan. Kendala lain di tempat pelatihan yang tidak tersedia listrik, juga harus mempersiapkan mesin generator dan kelengkapan pelatihan yang juga mengambil waktu pelatihan. Belum lagi harus menunggu guru-guru yang hadirnya tidak bersamaan dan cenderung terlambat. Belum lagi kendala individu guru yang hadir dengan membawa anak sehingga dalam mengikuti pelatihan kurang jenak dan runtut karena sambil mengisi anak.

\section{2) Pembiasaan Karakter Siswa}

Kegiatan lain yang utama di tempat penelitian adalah melakukan pembiasaan karakter kepada siswa di enam sekolah yang ada di Desa Barunang. Beberapa nilai karakter yang akan dibiasakan antara lain: a) disiplin, b) tanggung jawab, c) peduli lingkungan, d) peduli sosial, e) toleransi, f) jujur, j) bersahabat/komunikatif, h) kerja keras, dan i) cinta damai. Semua nilai tersebut dikemas ke dalam tema Perilaku Hidup Bersih dan RESPECT. Tema Perilaku Hidup Bersih akan membiasakan karakter peduli lingkungan, tanggung jawab, jujur, disiplin, kerja keras. Sedangkan pada tema RESPECT yang menanamkan sikap dan rasa hormat kepada diri sendiri dan orang lain akan melakukan pembiasaan nilai karakter toleransi, jujur, cinta damai dan peduli sosial. 


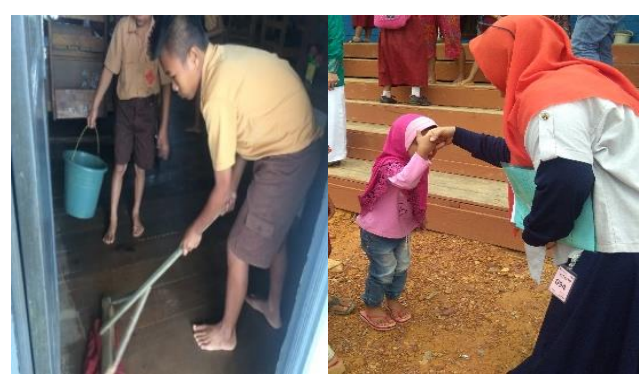

Gambar 3. Pembiasaan Karakter

Dengan mengusung tema Perilaku Hidup Bersih kegiatan pembiasaan yang dilakukan adalah meminta siswa membawa tanaman yang ada di sekitar rumah tempat tinggal siswa, dan dikenalkan dengan aturan kebersihan seperti: (a) mandi sebelum berangkat sekolah; (b) menggosok gigi sebelum berangkat sekolah; (c) setelah makan dan sebelum tidur, cuci tangan sebelum makan, setelah makan; (d) potong kuku agar rapi dan bersih; (e) buang sampah di tempat sampah; dan (f) menjaga tetap bersih dan rapi. Tanaman yang dibawa ke sekolah dan diletakkan di dalam kelas atau di luar kelas. Media yang dipakai untuk tanaman ada yang menggunakan tanah atau air. Dengan media yang berbeda berakibat pada keawetan usia tanaman karena air merupakan hal yang langka di Desa Barunang. Tabel berikut akan menggambarkan hasil pemantauan bagaimana siswa menjaga keawetan dan keutuhan tanamannya masing-masing.

Tabel 5. Pemantauan Tanaman Siswa

\begin{tabular}{|c|c|c|c|c|}
\hline \multirow{2}{*}{ Sekolah } & \multicolumn{4}{|c|}{ Periode Pantau } \\
\hline & I & II & III & IV \\
\hline $\begin{array}{l}\text { TK Tunas Bangsa } \\
\text { Sakakarangan }\end{array}$ & 18 & 14 & 9 & 6 \\
\hline $\begin{array}{l}\text { SD Tunas Bangsa } \\
\text { Sakakarangan }\end{array}$ & 24 & 20 & 16 & 14 \\
\hline $\begin{array}{l}\text { SDN Tumbang } \\
\text { Mamput }\end{array}$ & 42 & 34 & 28 & 21 \\
\hline SDN Barunang & 38 & 37 & 25 & 17 \\
\hline SD Pendarawah & 37 & 32 & 27 & 22 \\
\hline $\begin{array}{l}\text { SMPN } 4 \text { Kapuas } \\
\text { Tengah }\end{array}$ & 25 & 20 & 13 & 8 \\
\hline Jumlah & 184 & 157 & 118 & 88 \\
\hline
\end{tabular}

Sumber: Laporan dan Evaluasi Program (ALC Indonesia)

Tabel 5 memberikan informasi bahwa dari jumlah siswa yang ada tidak semua membawa tanaman dimana prosentase jumlah tanaman terkumpul (periode I) dan jumlah siswa berturut-turut 1) TK Tunas
Bangsa (42,8\%), 2) SD Tunas Bangsa (60\%), 3) SDN Tumbang Mamput (67,7\%), 4) SDN Barunang $(52,8 \%)$, 5) SD Pendarawah $(77,1 \%)$, dan 6) SMPN Kapuas Tengah (44,6\%). Hal ini berarti tidak mudah untuk membangkitkan kesadaran siswa untuk patuh pada ketentuan sekolah.

Hal lain yang bisa dilihat dari tabel tersebut terjadinya penurunan jumlah tanaman yang mestinya dirawat oleh siswa. Angka prosentase penurunan dapat dilihat pada pemantauan awal dan akhir dimana berturut-turut adalah: 1) TK Tunas Bangsa (66,67\%), 2) SD Tunas Bangsa (41,67\%), 3) SDN Tumbang Mamput (50\%), 4) SDN Barunang $(55,26 \%)$, 5) SD Pendarawah (40,54\%), dan 6) SMPN Kapuas Tengah (68\%). Tantangan terbesar dalam rangkaian tema ini ada di sekolah jenjang TK dan SMP yang penurunan jumlah tanamannya relatif tertinggi.

Sedangkan pada tema RESPECT, siswa dikenalkan dengan aturan kelas yang berisi: (a) mengangkat tangan sebelum bertanya atau menjawab; (b) menunjukkan rasa hormat dengan mengucapkan "tolong", "terimakasih" dan "mohon maaf"; (c) memelihara barang milik sendiri dan orang lain; (d) meminta ijin sebelum meminjam barang orang lain; (e) menyimak pembicaraan lawan bicara; (f) bersalaman dengan guru sebelum masuk kelas dan pulang sekolah; $(\mathrm{g})$ berbicara dengan sopan kepada teman, guru atau orang dewasa.

Instrumen lain yang juga digunakan dalam rangka RESPECT, juga diadakan SALAM PAGI sebagai "ritual" rutin siswa sebelum masuk kelas. Instrumen SALAM PAGI berisi pilihan siswa seperti Bersalaman, Kepal Semangat, Peluk, atau Toss. Pembiasaan ini juga dikenalkan dan dilatihkan kepada guru agar terbiasa melakukan empat gerakan tersebut.

\section{d. Daya Dukung Lingkungan}

Desa Barunang yang terdiri dari 3 dusun yang terpisah saling berjauhan dan jumlah warga yang juga tidak merata juga membedakan cara pandang umum 
10 | Asriana Kibtiyah, dkk : Program pembiasaan karakter ...

masyarakatnya terhadap pendidikan terutama terhadap keberadaan sekolah. Keberadaan sekolah di Desa Barunang dengan dusun-dusun yang ada secara umum disikapi dengan berbagai hal. Berikut ini merupakan hasil pengamatan dan hasil wawancara peneliti terhadap masyarakat sekitar.

\section{1) Cara pandang terhadap pendidikan}

Masyarakat Barunang dalam memandang pendidikan belum dianggap sebagai hal yang pokok dan penting apalagi menjadi sebuah investasi jangka panjang. Sebagian masih beranggapan pendidikan tidak memberikan dan menjanjikan apa-apa pada kehidupan mereka. Pola hidup masyarakat yang mengandalkan sepenuhnya sumberdaya alam berupa hutan masih demikian kuat. Hal tersebut membentuk kebiasaan memperoleh segala sesuatu tanpa harus membudidaya atau menanam terlebih dahulu.

Demikian halnya dengan pendidikan yang membutuhkan waktu lama untuk dapat memanen atau memetik hasilnya. Meskipun saat ini pendidikan yang disediakan tanpa harus mengeluarkan biaya. Sehingga dalam memandang pendidikan anak-anak mereka bukan hal yang pokok dan utama. Maka yang terjadi adalah sering sekali mengesampingkan sekolah anak-anak mereka daripada aktivitas lain di luar sekolah.

\section{2) Sikap orangtua terhadap keberadaan sekolah}

Terhadap keberadaan sekolah, baik yang diadakan oleh Pemerintah maupun perusahaan (PT ABB), masyarakat cenderung belum menganggap sebagai aset desa yang harus dijaga dan dirawat. Sebagai contoh, rusaknya pintu kamar mandi sekolah yang sengaja dirusak oleh warga yang ingin menggunakannya untuk keperluan sehari-hari, atau rusaknya kursi dan meja serta hilangnya buku atau peralatan sekolah, dan sebagainya.

Perilaku kurang peduli ini disebabkan karena sebagian warga beranggapan bahwa seluruh kebutuhan fasilitas sekolah itu akan dipenuhi oleh PT ABB sepanjang waktu. Sehingga jika ada kerusakan atau hilang atas fasilitas milik sekolah dianggap bukan persoalan. Inilah sikap yang menggantungkan segala kebutuhan warga kepada perusahaan.

Sebenarnya tidak ada yang salah jika warga atau masyarakat ikut menggunakan fasilitas sekolah seperti lapangan volley untuk wadah olahraga warga. Namun tidak jarang perilaku vandalis muncul yang mengakibatkan kerugian pada sekolah. Akhirnya ketika sekolah membutuhkan fasilitas tersebut sudah tidak bisa lagi digunakan karena rusak atau hilang.

\section{3) Tradisi dan budaya lokal terhadap sekolah}

Sebagai masyarakat yang sudah lama menetap dan memiliki tradisi serta budaya turun-temurun, juga memberikan pengaruh terhadap keberadaan sekolah. Agama Hindu Kaharingan yang dianut oleh mayoritas penduduk Desa Barunang yang bersuku Dayak memiliki banyak tradisi serta budaya, mulai dari kelahiran bayi, pernikahan hingga kematian yang kesemuanya dikemas dalam suatu upacara adat.

Tradisi dan budaya yang terpelihara tersebut di dalam suku Dayak yang penuh keguyuban dan kekerabatan itu juga memengaruhi partisipasi dan kehadiran siswa ke sekolah ketika ada peristiwa adat setempat. Siswa sering tidak hadir ke sekolah, atau bahkan guru juga turut tidak hadir karena mengikuti kegiatan adat setempat hingga berhari-hari.

Tradisi yang lain berkenaan dengan pola hidup keluarga yang sering keluarmasuk hutan yang dilakukan berhari-hari bahkan berminggu-minggu dengan mengajak seluruh anggota keluarga. Hal ini tentu akan mengganggu jadwal rutin sekolah anak. Namun hal semacam ini terlalu sering terjadi, sehingga anak ketinggalan materi pelajaran. Dampak terburuknya, anak kesulitan mengikuti pelajaran bersama teman-temannya dan 
akhirnya harus tinggal kelas. Hal ini apabila dibiarkan dalam jangka waktu yang lama akan berdampak kurang baik terhadap pembentukan karakter anak. Budaya terdekat anak merupakan faktor pembentuk karakter anak yang paling kuat memengaruhi, sebelum anak akhirnya akan membentuk budaya yang lebih luas (Afandi, 2011). Demikian pula yang disampaikan oleh Akbar (2010) bahwa salah satu cara pembentukan karakter anak adalah dengan mempelajari nilai-nilai kehidupan yang ada di sekitar rumah tempat tinggal dengan segala bentuk budaya dan tradisinya.

\section{Pembahasan}

Dari hasil penelitian di atas, peneliti mencoba melakukan analisis data dan pembahasan baik secara teoretis maupun praktis, serta melakukan sejumlah tindakan melalui pendampingan kegiatan di setiap sekolah.

\section{a. Program Pembiasaan Karakter}

Dengan mempertimbangkan kondisi dan skala prioritas atas kegiatan yang dirancang, maka melakukan pembiasaan atas karakter kepada siswa agar menjadi sesuatu yang melekat dalam keseharian pada kehidupan siswa. Hal ini selaras dengan yang dikatakan oleh Megawangi (2010) bahwa pendidikan karakter akan efektif apabila senantiasa dilakukan pengulangan terhadap perilaku positif secara terus-menerus. Perilaku baru yang dilakukan secara terus-menerus dan berkelanjutan akan membentuk kebiasaan, dan kebiasaan yang diulang-ulang akan membentuk karakter (Amri et al., 2013; Chatib \& Fatimah, 2015; Lickona, 2004; Poniman, 2018; Zubaedi, 2011)

Sesuai rencana, telah ditetapkan empat karakter dasar yang akan dikenalkan dan dibiasakan kepada siswa yaitu: (a) hidup bersih, (b) RESPECT (rasa hormat), (c) disiplin, dan (d) pantang menyerah. Diharapkan empat karakter dasar ini kelak akan menjadi bekal bagi setiap siswa dalam menapaki kehidupan di masa datang.
Empat karakter dasar ini juga menjadi ciri khas bagi perusahaan yang mendukung program ini. Pada periode ini, telah dilakukan dua karakter dasar yaitu RESPECT dan hidup bersih yang menjadi pola dalam membentuk dua karakter dasar tembahan.

Dalam mengajarkan rasa hormat (respect) kepada siswa melalui guru-guru yang dikenalkan dan dilatih terhadap karakter ini. Pada implementasinya, guru diminta memantau perilaku siswa seharihari selama di sekolah. Apabila terdapat perilaku yang menyimpang atau menyalahi perilaku respect, maka cepat-cepat guru memperbaikinya. Selain itu, guru juga harus memberikan contoh atas perilaku respect selama di sekolah, terutama jika berada di depan siswa. Upaya ini dapat mengurangi perilaku kekerasan sesama siswa secara signifikan.

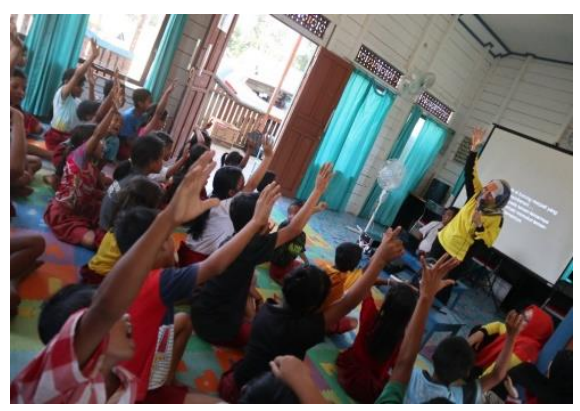

Gambar 4. Kegiatan Motivasi Siswa

Dipilihnya karakter respect ini karena dalam perilaku sehari-hari hubungan anak/orang muda kepada orangtua atau orang yang lebih dewasa tidak tampak ada rasa hormat dalam interaksi dan komunikasi. Dengan mengajarkan dan membiasakan perilaku respect yang rutin sehari-hari di sekolah akan memengaruhi perilaku siswa ketika berada di rumah dan lingkungan tempat tinggalnya (Lickona, 1991).

Namun oleh karena jam sekolah yang pendek, yaitu antara pukul 07.00-12.00 dimana efektif waktu belajar hanya 3 jam karena rata-rata sekitar pukul 08.00 siswa baru mulai belajar, dan tidak jarang siswa pulang lebih awal (pukul 10.00 atau lebih awal lagi jika ada upacara adat). Waktu belajar tersebut jika berlangsung dalam 
kondisi cuaca normal (kering) dan tidak hujan. Namun jika cuaca hujan yang berakibat kondisi jalan menjadi becek maka sebagian besar siswa dan guru terlambat hadir atau bahkan sams sekali tidak hadir ke sekolah karena kondisi cuaca.

Faktor kondisi cuaca yang tidak menentu tersebut berdampak pada kelancaran proses pembelajaran, termasuk program pembiasaan karakter di sekolah menjadi terhambat. Semakin sering terjadi keterlambatan ataupun ketidakhadiran guru maupun siswa tentu berpengaruh kepada proses pencapaian kemampuan siswa.

Dalam hal program pembiasaan karakter ini merupakan bagian dari penguatan pendidikan karakter yang disesuaikan dengan program sebagai sekolah binaan PT ABB.

\section{b. Manajemen Sekolah Pendalaman}

Sebagaimana telah disinggung di atas bahwa kondisi dusun-dusun Desa Barunang berada di area hutan yang jauh dari keramaian kota, dan dekat dengan areal tambang batubara sudah tentu memerlukan pengelolaan sekolah yang juga harus ditangani berbeda. Perbedaan geografis dan geokultural menjadi faktor penting yang wajib diperhatikan di dalam menangani sekolah-sekolah yang ada di pedalaman.

Sekolah di daerah perkotaan yang sangat lengkap dan dimudahkan oleh akses informasi dan fasilitas yang baik, sangat berbeda dengan kondisi di pedesaan atau bahkan di pelosok hutan pedalaman. Sedangkan sekolah di pedalaman tidak mudah mendapatkan akses maupun diakses informasi yang terbaru, serta tidak adanya fasilitas yang memadai. Sebagai contoh, gedung sekolah yang dibangun oleh Pemerintah hanya diperuntukkan kelas saja. Artinya, untuk sekolah dasar hanya ada enam lokal ruang kelas, dan tidak tersedia ruang kantor ataupun ruang guru.

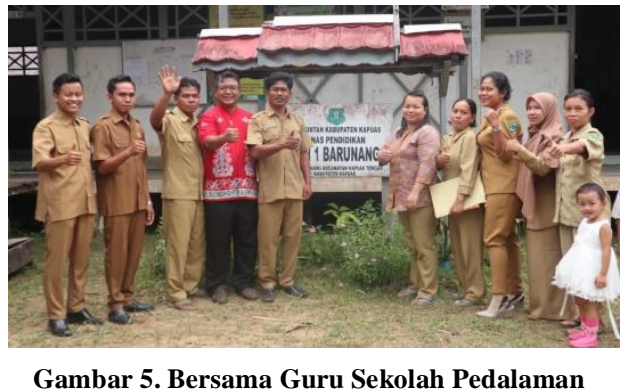

Sedangkan dalam kaitannya menuju sekolah ramah anak untuk semua sekolah yang diobrservasi, maka pengelolaan sekolah dengan kepemimpinan Kepala Sekolah yang mumpuni di daerah pedalaman. Peran Kepala Sekolah di sekolah-sekolah pedalaman menjadi sangat vital, mengingat dalam pengambilan keputusan yang menentukan arah kebijakan sekolah sangat dibutuhkan dan memperpendek alur birokrasi.

Jarangnya kehadiran pengawas sekolah maupun pejabat dari Dinas Pendidikan menambah pentingnya keberadaan Kepala Sekolah dalam mengawal proses pembelajaran sehari-hari. Sekolah yang tidak memiliki Kepala Sekolah definitif ataupun jarang hadirnya Kepala Sekolah tampak pada program yang dijalankan di sekolah. Sekolah tanpa adanya Kepala Sekolah dalam banyak program tidak berjalan dengan lancar dan tercapai tujuan secara optimal. Keberadaan dan peran Kepala Sekolah sangat penting mengingat kepala sekolah adalah seorang pemimpin unit belajar. Menurut Mulyasa (2004) bahwa untuk mewujudkan visi, misi, tujuan dan sasaran sekolahnya melalui programprogram yang dilaksanakan secara terencana dan bertahap maka dibutuhkan peran kepala sekolah yang tampil memimpin untuk menjalankan programprogramnya.

Keberadaan Kepala Sekolah akan memudahkan sekolah menjalankan semua program, termasuk terbentuknya sekolah yang ramah anak. Kepala sekolah akan mendesain secara bertahap lingkungan yang ramah anak melalui prosedurprosedur dan ketentuan-ketentuan yang sesuai UU Perlindungan Anak No.23/2002. 
Bahkan dalam pelaksanaan penguatan pendidikan karakter di sekolah, keterlibatan dan peran aktif dari kepala sekolah sebagai salah satu komponen utama yang mengimplementasikan proses penguatan pendidikan karakter agar lebih efektif (Sriwilujeng, 2017).

\section{c. Peningkatan Kualitas Guru}

Dengan kondisi pedalaman yang serba minim di hampir segala aspek akan sangat menentukan kuantitas dan kualitas guru yang berada di sekolah-sekolah wilayah pedalaman seperti Desa Barunang. Dari ketercukupan jumlah minimal guru yang ada untuk memenuhi setiap kelas juga belum bisa tercapai.

Penggunaan rasio guru dan siswa secara faktual tidak bisa diterapkan dikarenakan faktor non-teknis. Maka yang terjadi tidak jarang seorang guru harus melakukan berbagai tugas bersamaan yang terbilang tidak mudah dan tidak ringan. Hal ini bertambah beban bagi seorang guru apabila ada guru lain yang tidak hadir karena harus mengurus adminstrasi ke kota ataupun sakit atau terkendala cuaca.

Demikian pula faktor kualitas guru yang sangat ditentukan oleh latar belakang pendidikan dan perilaku minat belajar guru. Faktor kualitas guru di tempat penelitian dapat ditunjukkan pada sebagaimana tabel berikut.

Tabel 6.1. Pemantauan Kemampuan Guru

\begin{tabular}{|c|c|c|c|c|}
\hline \multirow{2}{*}{ No. } & \multirow{2}{*}{ Satuan Pendidikan } & \multicolumn{3}{|c|}{$\begin{array}{c}\text { Skor Guru } \\
\text { Rata-rata }\end{array}$} \\
\hline & & $\begin{array}{l}\text { Mem } \\
\text { baca }\end{array}$ & $\begin{array}{l}\text { Men } \\
\text { ulis }\end{array}$ & $\begin{array}{l}\text { Berh } \\
\text { itung }\end{array}$ \\
\hline $\mathbf{1}$ & TK-SD Tunas Bangsa & 70 & 68 & 60 \\
\hline 2 & SD Penda Rawah & 70 & 66 & 60 \\
\hline 3 & SDN Tumbang Mamput & 68 & 70 & 60 \\
\hline 4 & SDN Barunang & 67 & 68 & 60 \\
\hline \multirow[t]{2}{*}{5} & SMPN 4 Kapuas Tengah & 70 & 70 & 70 \\
\hline & Rata-rata keseluruhan & 69.0 & 68.4 & 62.0 \\
\hline
\end{tabular}

Tabel di atas mengisyaratkan bahwa dalam hal kemampuan dasar guru dalam membaca-menulis dan berhitung belum merata, namun secara umum menjunjukkan angka yang tidak cukup tinggi. Itu artinya, agar guru sampai pada tingkatan yang lebih tinggi dan berprestasi terbilang masih jauh.
Angka kemampuan menghitung dasar malah menunjukkan angka terendah. Itulah mengapa kebanyakan guru enggan mengajar ilmu Matematika terutama di kelas-kelas atas.

Sedangkan kualitas kemampuan pengelolan kelas pembelajaran, guru juga belum cukup baik. Rizal, dkk (2009) menyatakan bahwa sedikit sekali guru yang berkonsentrasi untuk belajar dan mengajar dengan baik. Jika guru bersedia untuk belajar maka guru akan terus berpikir dan mencari cara agar materi yang diajarkan dapat diterima dengan mudah oleh setiap siswa. Ketidakcakapan di dalam mengajar dan mengelola kelas pembelajaran seharihari disebabkan banyak hal, antara lain yang paling mencolok adalah latar belakang pendidikan guru. Sebagian besar guru yang bergelar sarjana S1 bukan berlatarbelakang ilmu kependidikan, bahkan sebagian merupakan lulusan SMA/SMK.

Di samping itu, jarangnya guru menerima pelatihan dan ketidakmampuan belajar mandiri menjadi penyebab guru belum cakap dalam mengajar. Padahal menurut Mariam Kronish, bahwa kemajuan sebuah bangsa serta-merta ditentukan oleh aktivitas pelatihan guru (Chatib, 2016). Keterbatasan akses dan budaya belajar yang belum cukup baik menjadikan guru kesulitan untuk dapat mengembangkan kemampuannya.

Dampak dari hal tersebut ini bahwa proses pembelajaran di sekolah-sekolah yang diobservasi juga dinilai kurang memenuhi standar isi dan standar kompetensi yang akan dicapai oleh setiap peserta didik. Berikut ini tabel tentang kemampuan guru dalam pembelajaran.

Tabel 7.Kemampuan Guru dalam Pengelolaan Kelas

\begin{tabular}{lccccc}
\hline \multirow{1}{*}{$\begin{array}{c}\text { Nama } \\
\text { Sekolah }\end{array}$} & \multicolumn{5}{c}{ Skor Pengelolaan Proses Pembelajaran } \\
\cline { 2 - 6 } & Openin & Kegiat & Closin & Penilai & Rata- \\
an inti & g & an & rata \\
$\begin{array}{l}\text { TK-SD } \\
\text { Tunas }\end{array}$ & 67.9 & 68.75 & 68.63 & 65.63 & 67.72 \\
Bangsa & & & & & \\
$\begin{array}{l}\text { SD Penda } \\
\text { Rawah }\end{array}$ & 70. & 68.75 & 68.00 & 67.25 & 68.50 \\
$\begin{array}{l}\text { SDN } \\
\text { Tumbang }\end{array}$ & 60.4 & 60.3 & 60.00 & 59.50 & $\mathbf{6 0 . 0 5}$ \\
Mamput & & & & & \\
\hline
\end{tabular}


14 | Asriana Kibtiyah, dkk : Program pembiasaan karakter ...

\begin{tabular}{lccccc}
\hline $\begin{array}{l}\text { SDN } \\
\text { Barunang }\end{array}$ & 67.50 & 67.38 & 66.63 & 66.63 & 67.03 \\
$\begin{array}{l}\text { SMP N 4 } \\
\text { Kapuas }\end{array}$ & 67.67 & 70.50 & 68.67 & 67.83 & 68.67 \\
$\begin{array}{l}\text { Tengah } \\
\begin{array}{l}\text { Rata-rata } \\
\text { Keseluruh } \\
\text { an }\end{array}\end{array}$ & 66.7 & 67.1 & 66.4 & $\mathbf{6 5 . 4}$ & 66.39 \\
\hline
\end{tabular}

Sumber: Laporan dan Evaluasi Program (ALC Indonesia)

\section{d. Solusi dan Pemecahan Masalah}

Dari data hasil temuan di atas, maka dalam kaitannya dengan program penguatan karakter dan menjadikan sekolah binaan PT ABB agar ramah anak diperlukan solusi dan pemecahan masalah sebagai berikut.

\section{1) Program Penguatan Pendidikan Karakter}

Program penguatan pendidikan karakter (PPK) akan dapat berlangsung secara berkelanjutan dan perlu mendapatkan dukungan dari orangtua dan masyarakat sekitar. Adapun langkah agar dapat meningkatkan program PPK di sekolah-sekolah binaan ini, antara lain: (a) program pembiasaan karakter harus dilaksanakan secara rutin dan berkelanjutan yang diperkaya dengan berbagai aktivitas yang menyentuh keseharian siswa. Misalnya, pendisiplinan melalui kegiatan kepramukaan, kerapihan berpakaian, dan sebagainya. Pembiasaan karakter ini merupakan salah satu strategi dalam pendidikan karakter, yaitu mengembangkan perilaku melalui kebiasaan (habituasi) baik dan selaras dengan nilai universalitas dan tradisi adat budaya bangsa (Afandi, 2011); (b) pelibatan orang tua yang mendukung program pembiasaan karakter dengan menciptakan lingkungan yang kondusif di rumah. Misalnya, orang tua harus menghentikan bicara keras dan tindak kekerasan kepada anak/siswa dalam hubungan interaksi dan komunikasi seharihari. Orang tua membutuhkan bimbingan dalam mengarahkan anak-anak mereka di jalur kemandirian secara bertanggung jawab (Illich, 2000); dan (c) kepala desa dan ketua adat harus terus-menerus menghimbau kepada seluruh warga agar mulai meniadakan secara bertahap kebiasaan berjudi dan mabuk saat upacara adat diselenggarakan. Warga diajak pada visi hidup sehat dan bermartabat sebagai bagian dari menghormati leluhur mereka.

\section{2) Desain Sekolah Ramah Anak}

Sekolah pedalaman juga dapat menjadi sekolah ramah anak, dengan merencanakan dan menindaklanjuti sejumlah hal, yaitu: (a) meningkatkan perilaku respect ke dalam kebiasaan sehari-hari dan budaya sekolah sehingga tidak terjadi peristiwa kekerasan, baik yang dilakukan oleh sesama siswa maupun oleh guru kepada siswa; (b) memperbaiki semua sarana dan prasarana belajar terutama yang berpotensi membahayakan keselamatan siswa dan guru; (c) Melakukan latihan penyelamatan kebencanaan secara rutin sebagai langkah antisipasi terjadinya bencana alam; (d) mengajak warga sekitar sekolah untuk menjaga dan merawat seluruh aset sekolah sebagai milik bersama yang tidak boleh digunakan untuk kepentingan pribadi ataupun kelompok.

\section{3) Keberadaan Kepala Sekolah}

Sedangkan untuk keberadaan kepala sekolah di sekolah-sekolah yang diteliti dan berada dalam lokasi pendalaman adalah: (a) Pemerintah Daerah khususnya Dinas Pendidikan di Kecamatan Kapuas Tengah hendaknya segera bertindak untuk mengevaluasi dan mempertimbangkan dengan sungguh-sungguh kinerja dari Kepala Sekolah yang dianggap sudah tidak mampu mengemban amanah sebagai Kepala Sekolah; (b) bagi sekolah yang belum ada kepala sekolahnya harus segera ditetapkan secara definitif mengingat keberadaan Kepala Sekolah sebagai pemimpin sangat penting; (c) Pemerintah selaku regulator dan pemegang kewenangan di dunia pendidikan wajib memberikan sanksi tegas kepada Kepala Sekolah dan guru yang sering mangkir dari tugas, terutama yang sudah berstatus sebagai aparatur sipil Negara (ASN). 


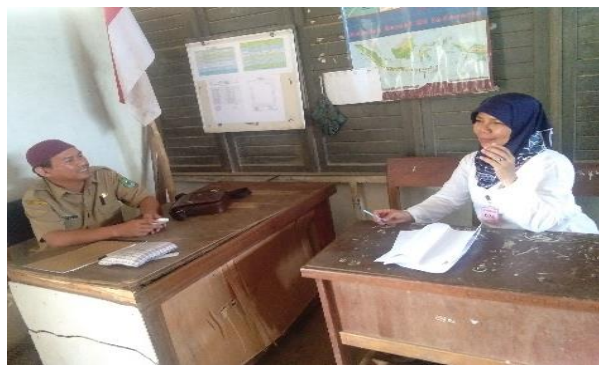

Gambar 6. Wawancara Kepala Sekolah

\section{4) Peningkatan Daya Dukung}

Guna meringankan beban kendala dan tantangan bagi sekolah dalam menjalankan program-programnya, maka diperlukan dukungan dari komponen seperti: (a) tokoh adat dan masyarakat, melalui himbauan dalam upacara adat yang sangat diyakini oleh sebagian besar masyarakat tentang membangun kesadaran dalam menempatkan pendidikan sebagai hal utama; (b) pejabat Pemerintahan, yang progresif melalukan pengawasan dan bantuan regulasi penempatan guru/tenaga pendidik yang mampu memberi iklim positif di sekolah-sekolah pedalaman; (c) perusahaan, yang akan terus memberikan fasilitas bagi guru-guru honorer dan guru bantu yang memiliki daya juang membangun pendidikan di sekolah pedalaman; dan (d) warga masyarakat, yang dengan penuh kesadarannya menjadikan sekolah sebagai sarana umum yang wajib dijaga dan dipelihara demi kepentingan bersama.

\section{Simpulan}

Dari uraian di atas, dari penelitian ini dapat disimpulkan: (1) kebijakan Pemerintah di bidang pendidikan dengan menghadirkan Kurikulum 2013 belum bisa berjalan dengan baik karena pemahaman guru serta proses pembinaan atas hal tersebut belum merata dilakukan kepada semua guru; (2) program penguatan pendidikan karakter yang dilakukan di sekolah-sekolah pedalaman melalui pembiasaan perilaku yang dilakukan secara praktis dalam keseharian siswa di sekolah; (3) kemampuan guru dan siswa dalam berliterasi terbilang rendah, sehingga memerlukan perhatian yang serius oleh Pemerintah setempat; (4) Kecakapan guru mengajar juga belum cukup baik, sehingga memerlukan proses didik dan latih yang dilakukan secara konsisten dari waktu ke waktu; (5) kehadiran kepala sekolah yang belum ajeg dan definitif menjadi penentu dan pengambil keputusan bagi sekolahsekolah pedalaman. Kepala Sekolah belum menjadi pemegang tanggung jawab tunggal terhadap sekolah; (6) sekolah mengalami kendala dalam menjalankan semua programnya, terutama yang berasal dari kultur masyarakat setempat; dan (7) sekolah-sekolah di pedalaman berpotensi menjadi sekolah ramah anak melalui perubahan pendekatan yang melibatkan unsur kepala desa, ketua adat, dan seluruh masyarakat.

\section{Daftar Pustaka}

Afandi, R. (2011). Integrasi Pendidikan Pendidikan Karakter Dalam Pembelajaran IPS Di Sekolah Dasar. Pedagogia, 1(No.1), 85-98.

Akbar, S. (2010). Model Pembelajaran Pembelajaran Nilai Dan Karakter Berbasis Nilai-Nilai Kehidupan Di Sekolah Dasar. Jurnal Ilmu Pendidikan, No.17(1). http://journal.um.ac.id/index.php/jip/a rticle/view/2619/1349

Amri, S., Jauhari, A., \& Elisah, T. (2013). Implementasi Pendidikan Karakter dalam Pembelajaran: Strategi Analisis dan Pengembangan Karakter Siswa dalam Proses Pembelajaran. Prestasi Pustakarata.

Chatib, M. (2015). Sekolahnya Manusia (Edisi Baru). Kaifa PT Mizan Pustaka.

Chatib, M. (2016). Gurunya Manusia (Baru Cet. I). Kaifa PT Mizan Pustaka.

Chatib, M., \& Fatimah, I. N. (2015). Kelasnya Manusia: Memaksimalkan 
16 | Asriana Kibtiyah, dkk : Program pembiasaan karakter ...

Fungsi Otak Belajar dengan Manajemen Display Kelas (Cetakan I). Kaifa PT Mizan Pustaka.

Darmadi, H. (2011). Metode Penelitian Pendidikan. Alfabeta CV.

Delors, J., Al Mufti, I. 'am, Amagi, I., Carniero, R., Chung, F., Geremek, B., Gorham, W., Kornhauser, A., Manley, M., Quero, M. P., Savane, M. A., Singh, K., Stavenhagen, R., Suhr, M. W., \& Nanzhao, Z. (1999). Learning: The Treasure Within. Unesco Publishing. http://unesdoc.unesco.org/images/001 0/001095/109590eo.pdf

Freire, P. (1985). The Politics of Education: Culture Power and Liberation. Greenwood Publishing Group.

Gafuri, A. (2015). Pengembangan Model Manajemen Pendidikan Karakter dengan Teknik Pendampingan Guru pada Sekolah Menengah Pertama. Pascasarjana UM.

Illich, I. (2000). Bebaskan Masyarakat dari Belenggu Sekolah (S. Keraf, Trans.; II). Yayasan Obor Indonesia.

Iskandar. (2009). Metodologi Penelitian Kualitatif (Cet. I). Gaung Persada.

KlikLegal.com. (2018, Desember). Mengenal Sejumlah Regulasi yang Mengatur CSR di Indonesia. https://kliklegal.com/mengenalsejumlah-regulasi-yang-mengaturcsr-di-indonesia/

Lickona, T. (2004). Character Matter. A Touchstone Book.

Megawangi, R. (2010). Sekolah Berbahaya Bagi Perkembangan Karakter Anak?: Solusi Bagaimana Mempersiapkan Sekolah Menjalankan Pendidikan Karakter. Indonesia Heritage Foundation`. http://repository.ut.ac.id/2486/1/fkip2 01002.pdf

Moleong, J. L. (2000). Metodologi Penelitian Kualitatif Edisi Revisi. PT. Remaja Rosdakarya.

Mukhtar, U., \& Zuraya, N. (2017, February 22). Indonesia Peringkat Tertinggi Kasus Kekerasan di Sekolah. Republika.Co.Id. http://nasional.republika.co.id/berita/ nasional/umum/17/02/22/olqnn2383indonesia-peringkat-tertinggi-kasuskekerasan-di-sekolah

Mulyasa, E. (2004). Menjadi Kepala Sekolah Profesional. Remaja Rosda Karya.

Nawawi, H. (2003). Metode Penelitian Bidang Sosial (Cet ke-10). Gadjah Mada University Press.

Poniman, F. (2018). Pancarona. Yayasan STIFIn.

Qodar, N. (2015, March 15). Survei ICRW: 84\% Anak Indonesia Alami Kekerasan di Sekolah. Liputan 6. : http://news.liputan6.com/read/219110 6/survei-icrw-84-anak-indonesiaalami-kekerasan-di-sekolah

Rizal, A., Sidi, I. D., \& Darma, S. (2009). Dari Guru Konvensional Menuju Guru Profesional. Grasindo.

Sasongko, D. (2017). Ditampar guru, siswi di Batu laporkan gurunya [Berita]. Merdeka.com. https://www.merdeka.com/peristiwa/ ditampar-guru-siswi-di-batulaporkan-gurunya.html

Seftiawan, D. (2017, November 23). 7 dari 10 Siswa Pernah Alami Kekerasan di Sekolah. Pikiran Rakjat. http://www.pikiranrakyat.com/pendidikan/2017/11/23/7dari-10-siswa-pernah-alamikekerasan-di-sekolah-414380 
17| Asriana Kibtiyah, dkk : Program pembiasaan karakter ....

Setkab RI, H. (2017). Inilah Materi Perpres No. 87 Tahun 2017 tentang Penguatan Pendidikan Karakter [Berita]. Setkab RI. http://setkab.go.id/inilah-materiperpres-no-87-tahun-2017-tentangpenguatan-pendidikan-karakter/

Sonhadji, A. (2014). Manusia, Teknologi dan Pendidikan. UM Press.

Sriwilujeng, D. (2017). Panduan Implementasi Penguatan Pendidikan Karakter. Esensi, Erlangga Group.

Sugiyono. (2015). Metode Penelitian Pendidikan (Pendekatan Kuantitatif, Kualitatif,dan $R \& D)$ (Cet ke-21). Alfabeta CV.

Sugiyono. (2017). Metode Penelitian \& Pengembangan. Alfabeta CV.

Sukardi. (2008). Metodologi Penelitian Pendidikan: Kompetensi dan Praktiknya (Cet ke-6). Bumi Aksara.

Sukmadinata, N. S. (2015). Metode Penelitian Pendidikan (11th ed.). PT Remaja Rosdakarya.

Ulfatin, N. (2015). Metode Penelitian Kualitatif di Bidang Pendidikan: Teori dan Aplikasinya. Media Nusa Creative.

Ulina, A. (2013, April 7). Kekerasan Psikis yg Dialami Anak di dalam Dunia Pendidikan. Kompasiana. https://www.kompasiana.com/www.a rthadollskompasiana.com/kekerasanpsikis-yg-dialami-anak-di-dalamduniapendidikan_552fce7b6ea834d33f8b4 $5 b 7$

Wikipedia. (2011). Barunang, Kapuas Tengah, Kapuas [Map]. https://id.wikipedia.org/wiki/Barunan g,_Kapuas_Tengah,_Kapuas

Yamin, M. (2012). Sekolah yang Membebaskan. Madani.
Zubaedi. (2011). Desain Pendidikan Karakter: Konsepsi dan Aplikasinya dalam Lembaga Pendidikan. Kencana. 